\title{
The Environmental Impacts of Agricultural Trade: A Systematic Literature Review
}

\author{
Jeremiás Máté Balogh * (1) and Attila Jámbor \\ Department of Agricultural Economics and Rural Development, Corvinus University of Budapest, Fővám tér 8, \\ 1093 Budapest, Hungary; attila.jambor@uni-corvinus.hu \\ * Correspondence: jeremias.balogh@uni-corvinus.hu; Tel.: +36-1-482-5320
}

Received: 13 January 2020; Accepted: 4 February 2020; Published: 5 February 2020

check for updates

\begin{abstract}
In line with the development of international trade, environmental concerns have arisen as a global problem. International trade has the potential to increase environmental externalities such as transboundary pollution, deforestation, transportation and production relocation avoiding environmental standards. The share of agricultural goods in total export reached $15 \%$ in 2017 . Since 2002, the proportion of unprocessed agricultural products have more than doubled, while the volume of processed goods in global trade has tripled. Despite the importance of agricultural trade worldwide, the number of studies exploring the trade-agriculture-environment nexus has so far been limited. This paper aims to provide an overview of the environmental impacts of agricultural trade based on the international economics literature published in recent years by way of a systematic literature review. Results suggest that most recent environmental studies do not view extended trade or trade liberalization in agriculture favourably. Only a limited number of papers state that a country or countries' environment could benefit from agricultural trade, and only a few researchers have found that agricultural trade did not have any significant influence at all, or have instead found the effects on the environment to be ambiguous. Finally, the research reveals the most important consequences of pollution and offers potential solutions.
\end{abstract}

Keywords: agricultural trade; environmental pollution; climate change; water; global and local impacts

\section{Introduction}

Agriculture faces new challenges such as feeding the world, meeting the demand for safe and nutritious food in line with rising world populations, increasing urbanization and growing incomes. Agriculture also generates jobs, and supports the livelihoods of billions of rural people across the Earth, especially in developing countries. Moreover, agriculture plays a role in ensuring the sustainability of natural resources and biodiversity, particularly in light of a changing climate [1]. Agricultural production and trade also need to catch up to meet the increasing demand for food in developed and developing countries.

Global agricultural trade has grown significantly during recent decades and experienced an annual growth of $6 \%$ from 2000 to 2016 [1]. Agricultural products show the most significant increase, growing by $3.1 \%$ per year and rising by $36 \%$ from 2008 to 2018 . The top 10 exporters of agricultural products (European Union, the United States, Brazil, China, Canada, Indonesia, Thailand, India Australia, Mexico) together accounted for $72 \%$ of total world exports in 2018 [2]. The most significant increases in exports of agricultural products within the top 10 exporters were recorded by China (9\%), Brazil (6\%) and Mexico (6\%) in 2018 [2]. Emerging economies such as Brazil, China, India and Indonesia were responsible for the majority of this growth as they accounted for $14.5 \%$ of global export value in 2016, as compared with $8.5 \%$ in 2000 [1]. 
In line with the expansion of international trade, environmental concerns have emerged as a global problem. International trade might foster environmental externalities (increasing pollution or degradation of natural resources) and is responsible for production growth, transboundary pollution, resource trade, transportation and production relocation avoiding environmental standards. Furthermore, trade acceleration and liberalization may facilitate specialization in pollution-intensive activities [3].

Agricultural trade also has indirect environmental effects as it displaces farmers onto marginal lands leading to deforestation and soil erosion. In many developing countries, the area devoted to export crops increases. In some cases, the environmental effects of shifting to export crops can be significant and harmful. The trade of toxic wastes or endangered species has visible environmental impacts [4].

Moreover, trade is also related to environmental pollution, associated greenhouse gas (GHG) emission and climate change. Garsous [5] shows that carbon emissions from fossil fuel combustion were embodied in imports and exports for 63 countries and 34 industries between 1995 and 2011.

However, trade might also in some ways positively affect the environment. For instance, free trade may lead to more effective environmental management, promote more efficient production, reduce energy use and improve access to new technologies [3].

Despite the importance of agricultural trade in the world, studies exploring the environmenttrade-agriculture nexus generally address agricultural production as a potential source of environmental pollution, thereby neglecting the role played by trade. Consequently, this paper aims to provide an overview of the environmental impact of agricultural trade based on the international economics literature published in recent years through a systematic literature review. The article aims to analyse the environmental impacts of agricultural trade at global and local levels. Our research questions are, therefore, as follows: What are the environmental impacts of agricultural trade? How can these impacts be classified? What kinds of solutions exist to help handle the impacts?

In this study, we narrowed the scope of the research to agricultural trade, although it has to be acknowledged that other factors—which are not addressed in this research—such as outdated machinery, lack of technology, transition to environmentally friendly techniques and innovative practices in the agricultural sector are also potential engines of pollution in developing and developed countries.

The paper is structured as follows. Section 2 describes how our sample was constructed together with some basic descriptive statistics. Section 3 shows the results of the review by different sections, followed by our conclusions.

\section{Materials and Methods}

To obtain a comprehensive review of the environmental impacts of agricultural trade, an extended online search was conducted using the following electronic databases: Scopus and Web of Science. The combination of keywords "agri" and "trade" and "environment" (search string: TITLE-ABS-KEY (agri AND trade AND environment) were used and the search had to appear in the title, abstract or keywords. Only materials written in English were selected and the authors were concentrated only on scientific journal articles-book chapters or books were dropped from the dataset. We restricted our analyses for empirical articles published between 1990 and 2019.

The initial search obtained 168 entries, out of which 24 were duplicates, suggesting a generally low number of articles written on the topic. To ensure that only relevant articles were included in the final analysis, the online software Covidence was used. The screening was independent, but then the authors met to discuss "conflicting" articles. This initial screening led to 57 articles being excluded. The remaining 87 articles were also screened by both authors and then we ended up to 65 publications relevant for the systematic literature review. Figure 1 provides an overview of the whole selection process. 


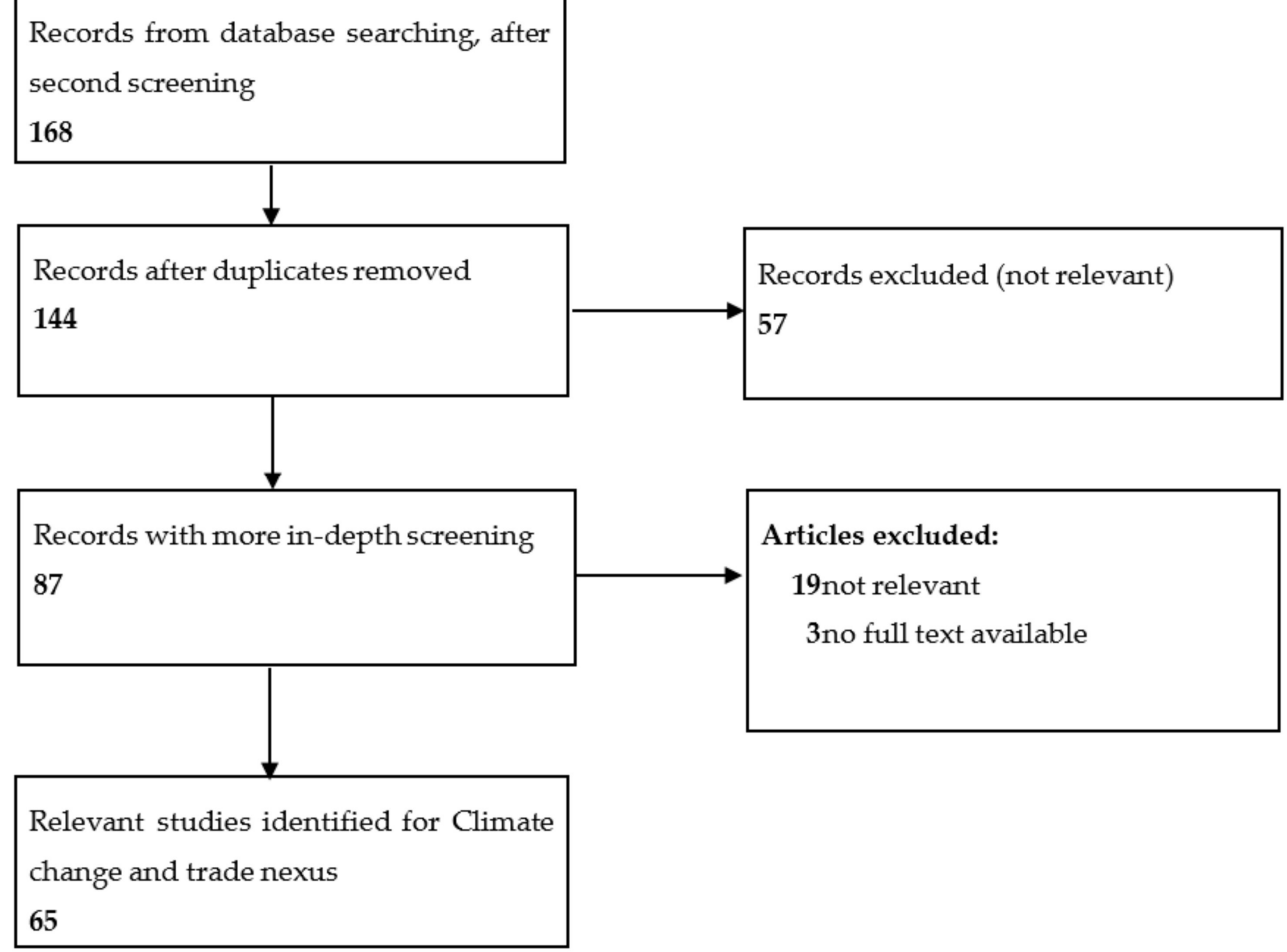

Figure 1. Overview of the literature selection process. Source: Own composition.

Based on the review of the relevant articles, we created 12 trade-related categories: the most significant part of the studies dealt with trade-related climate change (38) and water use (10) issue. The third most frequent sub-topic was trade and deforestation, which was followed by land-use change (4) as well as trade liberalization (3). Besides, highly infrequent topics were found, such as fish production and trade, the impact of trade agreements, phosphorus flows, food security, filamentous green algae pollution, nitrogen trading, environmental regulation, and environment protection. Figure 2 shows the main topics of the articles analysed.

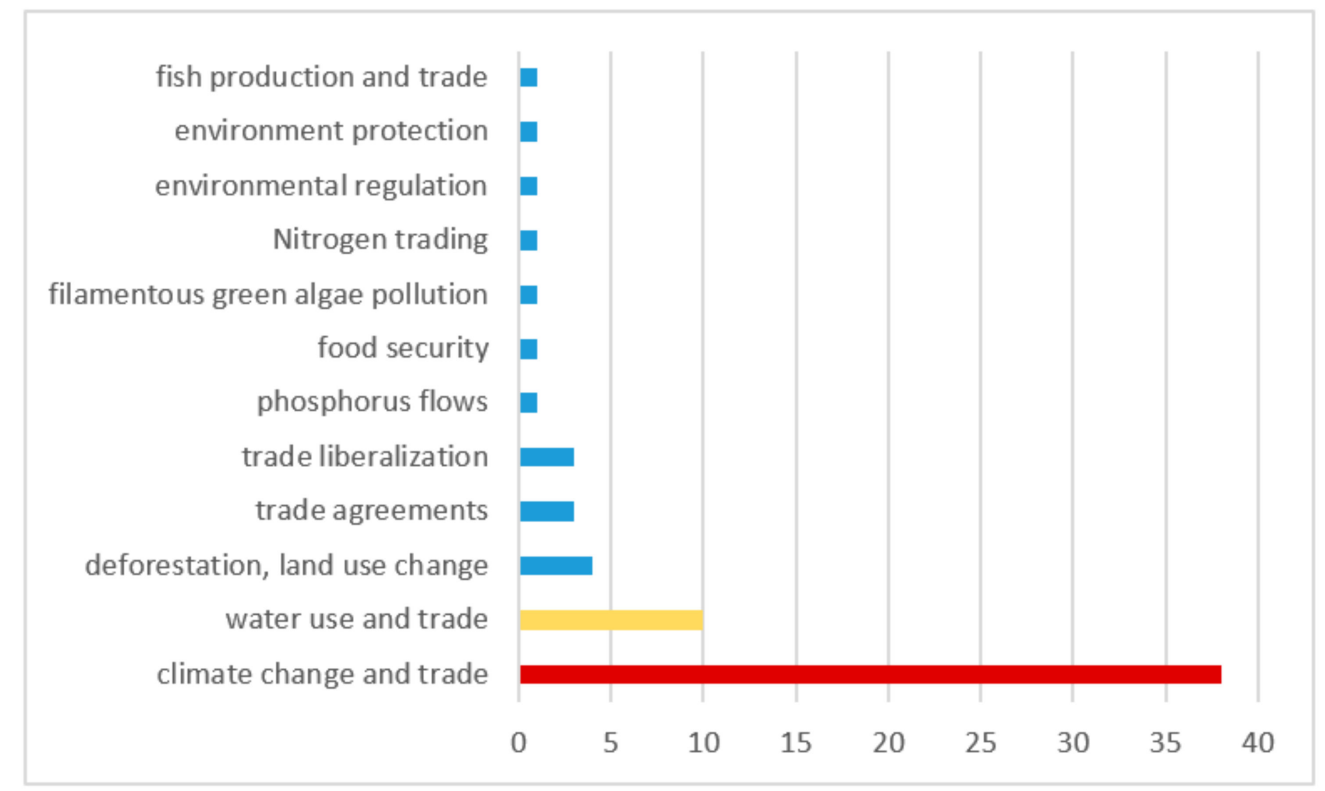

Figure 2. Topics of the articles analysed. Source: own composition. 
Regarding the representation of countries considered in the selected empirical literature, the United States (10) and China (9) were the two most popular countries analysed on the topic of the trade-environment relation, followed by Mexico (6), the EU (5) and the South American region (Brazil, Argentina). Most of the studies (21) interpreted the issue of environment and trade as a global problem (Figure 3). In turn, many articles applied country or regional level of analysis indicating that environmental pollution might have a local impact (e.g., deforestation, land-use change).

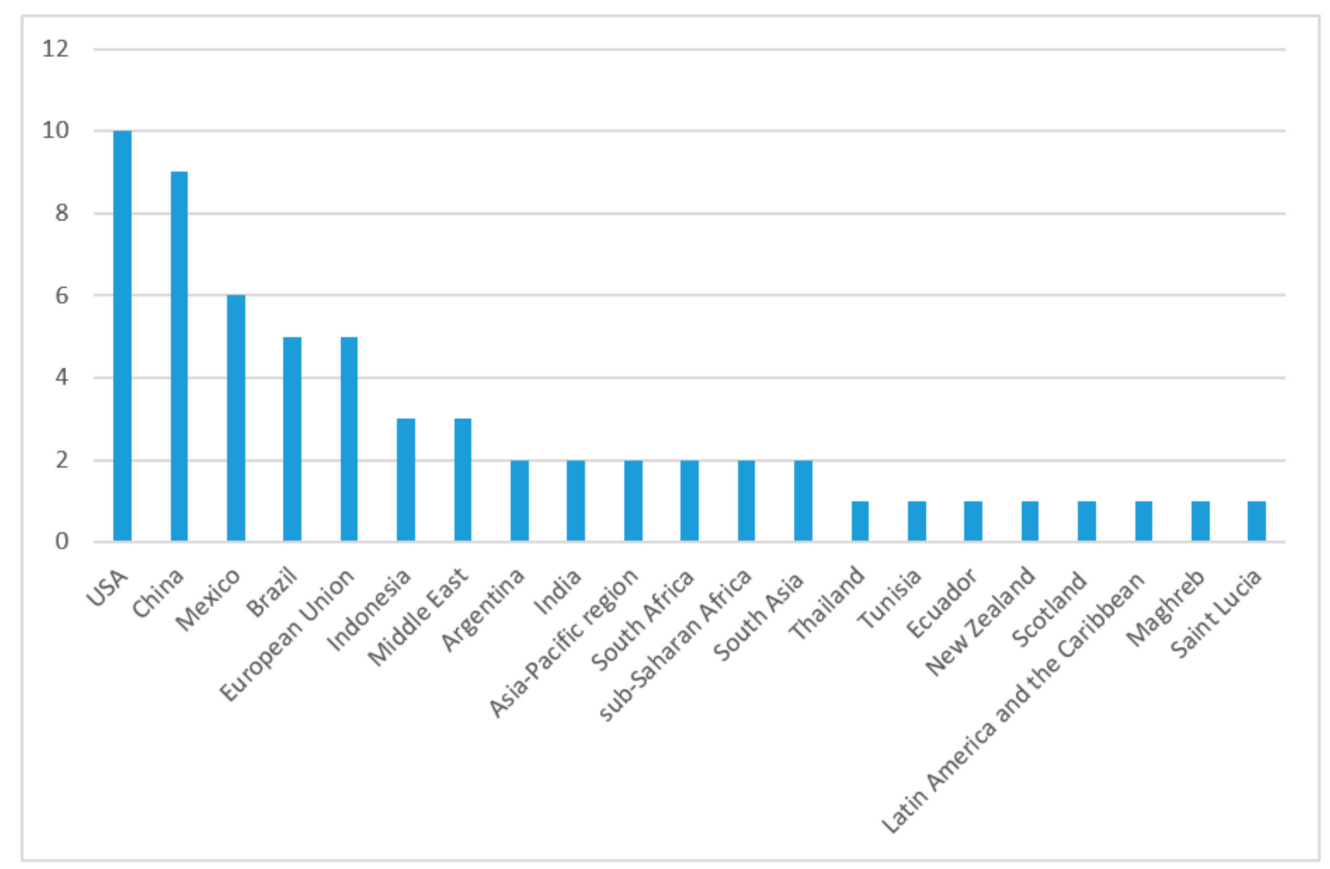

Figure 3. Frequency of countries and regions analysed in the environment and agri-trade literature.

Source: own composition.

Regarding the sub-regions analysed, four endangered regions were investigated by the literature: Mato Grosso (Brazil), Amazonian rainforest (Brazil), Yangtze River region (China) and Haihe River Basin (China). Both livestock and crop production was taken into consideration in the literature as potential local engines of trade-related environmental pollution. Regarding the former, meat and dairy products and fishery sectors were considered and as to the latter, maize production, horticultural production (tomato, pepper, cucumber), banana export, water-intensive crops, soybean, sugarcane, palm oil, rubber and coffee, green algae were also discussed. Finally, water-intensive agricultural goods and biomass trade were correlated with environmental problems as well.

Regarding the proportion of the methodology used in the selected articles, economic modelling was the most popular $(66 \%)$, followed by descriptive statistics and graphical analysis $(14 \%)$, while qualitative techniques (1\%) and case studies (1\%) were applied to the least extent (Figure 4). 


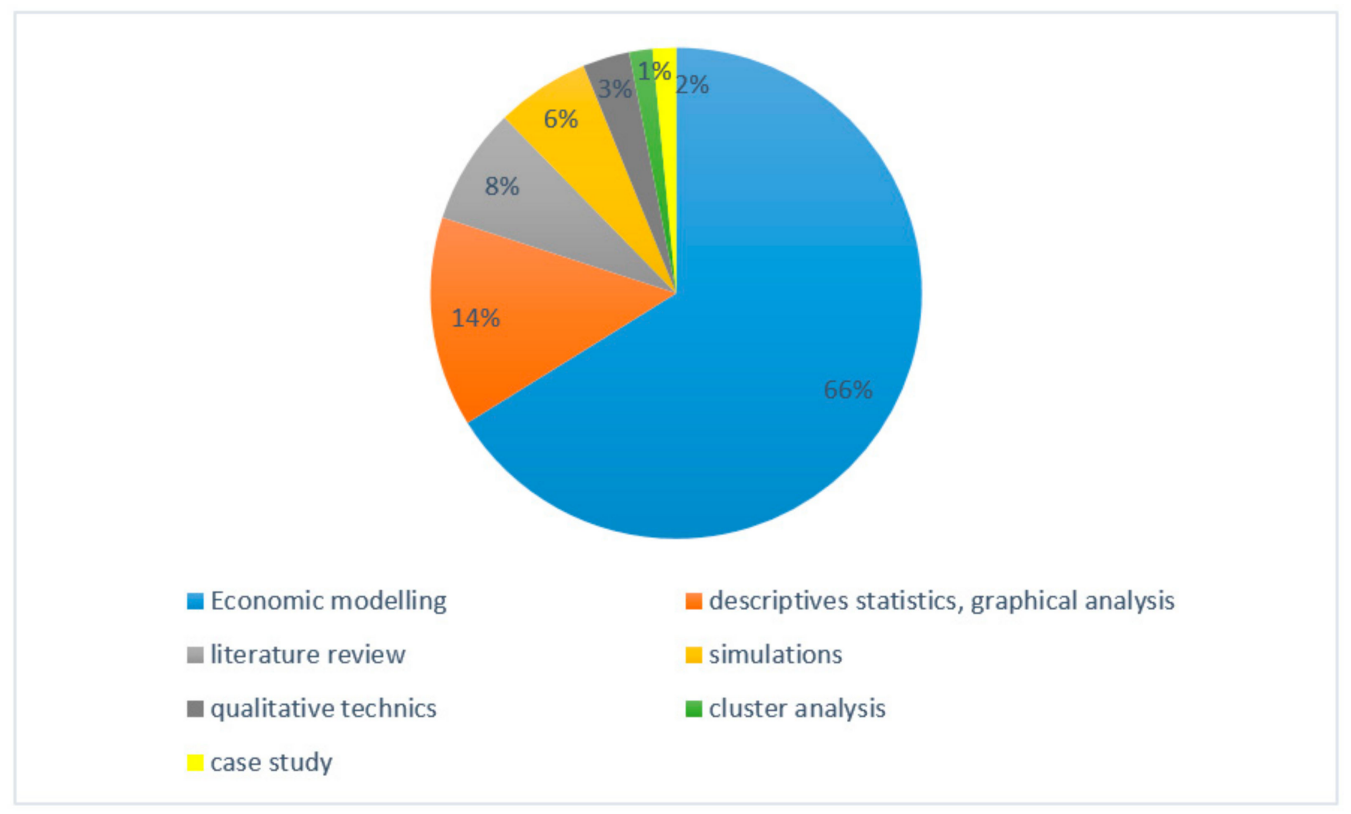

Figure 4. Research methods used by literature. Source: own composition based on the sample.

\section{Results}

It is apparent from our sample described above that articles retrieved from the literature were written on three main topics: 'climate change', 'water use' and 'other issues'. Most of the studies focused on trade-related climate change issues (GHG emission, deforestation, land-use change induced by trade), while some of them analysed the effect of trade on water management and pollution (irrigation system, trade of water-intensive products, virtual water trade). Finally, only four of them investigated a different research topic from agricultural trade: carbon trade in Scotland [6], consequences of stylized food security policies and globalization of agricultural markets [7], filamentous green algae pollution [8] and reductions in $\mathrm{N}$ losses at the farm level [9].

The literature was analysed and categorized according to the following statements referring to the distinct effect of agricultural trade on the environment:

- Agricultural trade negatively affects the environment (indicates pollution),

- Agricultural trade does not have a significant effect on the environment (pollution),

- Agricultural trade has a positive (advantageous) influence on the environment (decrease pollution),

- Agricultural trade might have ambiguous (a negative or a positive) impact on the environment (pollution).

In total, 21 articles out of the 65 stated that trade or agricultural trade was damaging the environment or causing pollution. In other words, these articles declared that trade contributed to environmental pollution and stimulated climate change through GHG emission (Table 1). 
Table 1. Summary of articles by the various effects of agricultural trade on the environment.

\begin{tabular}{|c|c|c|c|}
\hline $\begin{array}{c}\text { Trade or Agricultural Trade Is Harmful } \\
\text { to the Environment }{ }^{1}\end{array}$ & $\begin{array}{l}\text { Agricultural Trade Does Not Influence } \\
\text { the Environment }\end{array}$ & $\begin{array}{l}\text { Agricultural Trade Has Positive Effects } \\
\text { on the Environment }\end{array}$ & $\begin{array}{l}\text { Ambiguous (Positive or Negative) } \\
\text { Effects of Agricultural Trade on the } \\
\text { Environment Are Also Possible }\end{array}$ \\
\hline Abler and Pick (1993) & Bourgeon and Ollivier (2012) & Cors $(2000)$ & Antonelli et al. (2017) \\
\hline Appendini and Liverman (1994) & Beghin et al. (1997) & Carter (1993) & Belton and Little (2008) \\
\hline Chakravorty et al. (2007) & Eickhout et al. (2007) & Dang and Konar (2018) & Biewald et al. (2014) \\
\hline Chang et al. (2016) & & Hassan (1997) & Boerema et al. (2016) \\
\hline Chaudhary and Kastner (2016) & & $\begin{array}{l}\text { Leitao (2011) Martinez-Melendez and } \\
\text { Bennett (2016) }\end{array}$ & Buckingham (1998) \\
\hline Chen et al. (2019) & & Baker et al. (2018) & Damodaran (2002) \\
\hline De Oca (2008) & & Billen et al. (2015) & Johansson et al. (2006) \\
\hline Drabo (2017) & & Hallstrom et al. (2004) & Saunders et al. (2006) \\
\hline Flachsbarth et al. (2015) & & Jebli and Youssef (2017) & Schmitz et al. (2013) \\
\hline \multicolumn{4}{|l|}{ DeFries et al. (2013) } \\
\hline \multicolumn{4}{|l|}{ Henders et al. (2015) } \\
\hline \multicolumn{4}{|l|}{ Iriarte et al. (2014) } \\
\hline \multicolumn{4}{|l|}{ Lee and Zhang (2009) } \\
\hline \multicolumn{4}{|l|}{ Moon (2011) } \\
\hline \multicolumn{4}{|l|}{ Nesme et al. (2018) } \\
\hline \multicolumn{4}{|l|}{ Rauf et al. (2018) } \\
\hline \multicolumn{4}{|l|}{ Saikku et al. (2012) } \\
\hline \multicolumn{4}{|l|}{ Schmitz et al. (2015) } \\
\hline \multicolumn{4}{|l|}{ Yau et al. (2018) } \\
\hline \multicolumn{4}{|l|}{ Walters et al. (2017) } \\
\hline Weinzettel and Wood (2018) & & & \\
\hline
\end{tabular}


It should be mentioned that usually, a local impact (soil erosion or GHG emission) of a global factor (agricultural trade) causes more problems for a given nation or country than for the whole world. In this research, we interpreted agricultural trade as being an international, global or regional phenomenon, whereas in contrast, environmental pollution is often responsible for local problems analysed by the articles.

\subsection{Studies Analysing the Negative Effects of Trade on the Environment}

Most of the articles in the selected literature highlighted the negative effects of agricultural trade on the environment (stimulating climate change and environmental pollution) locally. On the one hand, trade expansion along with agricultural production and industrialization were the major engines of pollution globally. On the other hand, increasing greenhouse gas emissions, drier climate, deforestation, land-use change, losses in ecosystem services were found to be the major consequences of trade locally.

Appendini and Liverman [10] described how agricultural policy and climatic conditions had influenced maize production and food security in Mexico. The authors suggested that global warming presented a threat to local and national food security when farmers were unable to adapt to a drier climate or if importing from other regions became more expensive. Saunders et al. [11] investigated bilateral trade between New Zealand and the EU and suggested that trade liberalisation increased greenhouse gas emissions on the New Zealand side but decreased on the EU side. Similarly, Lee and Zhang [12] suggested that trade liberalisation caused higher energy use and carbon emissions to rise, which was especially a problem in poor developing countries.

Among others, Schmitz et al. [13] showed that trade liberalisation led to the expansion of deforestation in Amazonia. Furthermore, in line with Lee and Zhang [12] and Schmitz et al. [13], Flachsbarth et al. [14] pointed out that further trade liberalization would lead to more environmental pressures in some regions across Latin America.

Following the authors above, Moon [15] was against free trade in agriculture and showed that free trade was not able to solve the differentiated problems of countries and regions related to the environment. Besides, Rauf et al. [16] found that trade openness was worsening the environment in China.

The environmental effects of virtual water trade were investigated by many articles (Zhao et al. [17], Zhang et al. [18]). On the one hand, Zhao et al. [17] discovered that virtual water embodied in exported and imported products, especially those who were re-exported, changed water footprint and balance to a significant extent in China. On the other hand, Zhang et al. [18] suggested that China was a virtual net water exporter accounting for $2.1 \%$ of its renewable and $8.6 \%$ of its total water use.

Land-use change related to carbon emission was also revealed as the main contributor to climate change. In this context, Saikku et al. [19] analysed the effect of biomass trade on the land-use change as well as carbon emissions and suggested that $15-32 \%$ of total agricultural land and emissions associated with land-use change in Brazil and Indonesia were due to bovine meat and palm oil exports. In addition, DeFries et al. [20] confirmed that the ecological, hydrological and social consequences of land-use change for export-oriented agriculture were applicable in about one-third of all tropical forest countries in 2000-2005. From the ecological perspective, Henders et al. [21] indicated that land-use change and carbon emissions associated with the production and exports of forest-risk commodities highlighted the growing influence of global markets in deforestation dynamics.

In a few studies, banana trade was mentioned as a significant component of carbon emission. Iriarte et al. [22] stated that the principal contributors to the carbon footprint were found to be on-farm production and overseas transport in the case of banana export from Ecuador. To confirm this, Walters et al. [23] inferred that the abandonment of land due to banana trade restrictions was favourable to the environment.

Last but not least, a large magnitude of losses in tropical ecosystem services through international trade in Brazil, Indonesia, Thailand, India, Malaysia and Vietnam were confirmed by Chang et al. [24].

Chaudhary and Kastner [25] analysed the impact of trade on biodiversity and found that $17 \%$ of total species loss was devoted to domestic consumption. Exports from Indonesia to USA and China 
embodied the highest environmental impacts ( 20 species lost at the regional level). They added that industrialized countries with high per capita GDP tended to be major net importers of biodiversity from developing countries from the tropical region.

A limited amount of studies dealt with emissions associated with domestic consumption and meat consumption. Drabo [26] highlighted that the proportion of primary commodity export in agricultural production increased greenhouse gas emissions. Yau et al. [27] showed that trade-related emissions to the consumption of meat and dairy products were higher than Hong Kong's total greenhouse gas emissions.

Chakravorty et al. [28] investigated the relationship between agricultural industrialization and the environment focusing on livestock production in developing countries. Moreover, they argued that environmental degradation caused by agricultural industrialization may pose major problems on production intensity, resulting in generally lower public health standards in urban areas of developing countries. Moreover, they emphasised that globalization and expanding the free trade regime in the world called for an urgent need for developing countries to install inspection and enforcement mechanisms to minimise the adverse effects of trade on the environment.

Finally, Weinzettel and Wood [29] and Nesme et al. [30] pointed out the harmful effects of trade expansion. Nesme et al. [30] analysed the role of agricultural trade in global phosphorus flows and found an eight-fold increase in global phosphorus flows through trade from 1961 to 2011, generally making phosphorus exporters susceptible to the volatility of the mineral phosphorus fertilizer market. Furthermore, Weinzettel and Wood [29] evaluated the carbon footprint of Chinese exports and showed that domestic consumption decreased the footprint of international trade.

\subsection{No Significant Effect of Agricultural Trade on the Environment}

Only a few studies (4 of 65) suggested that agricultural trade did not affect environmental pollution and hence climate change. Regarding the US example, Ervin [31] discussed the effects of liberalised trade on environmental quality and made conceptual and empirical contributions regarding NAFTA and GATT. In line with this type of research, Beghin et al. [32] did not find evidence of wholesale environmental degradation in agriculture induced by free trade in Mexican agriculture. Furthermore, Chen et al. [33] explored that the inter-industry association mainly promoted the embodied carbon outflow in the Yangtze River (China). They highlighted the role of the consumer's responsibility in reducing trade-related emission. As a final point, Bourgeon and Ollivier [34] concluded that trade liberalisation either increased or decreased worldwide emissions depending on regional comparative advantages compared to autarky at country level.

\subsection{Agricultural Trade Has a Positive (Advantageous) Effect on the Environment}

The second biggest group of articles (10) argued that agricultural trade, in certain cases, might have a positive effect on the environment, and may help to reduce environmental pollution. Carter [35] in this regard showed that shifting food production from rich to poor countries would reduce global agricultural pollution, therefore, freer trade is said to be more environmentally friendly. Following Carter [35], Hassan [36] added that trade liberalisation for agricultural products led to environmental improvement as their production associated with environmental externality.

What is more, Leitao (2011) [37] found a negative relationship between carbon dioxide emissions and intra-industry trade by analysing the relationship between agricultural intra-industry trade and the environment in the US. In addition to Leitao [37], Billen et al. [38] underlined that in the most deficient regions (the Maghreb, the Middle East, sub-Saharan Africa, and India), with less recourse to inter-regional trade generally produced fewer $\mathrm{N}$ losses to the environment, improving agricultural performance.

In addition, Cors [39] confirmed that trade and environmental agreements aspired to be mutually supportive, but to do so, this requires substantial harmonisation between agreements at the international level. Moreover, Martinez-Melendez and Bennett [40] revealed that the US-Mexican crop trade reduced the environmental costs of agriculture between the two countries. 
In their research, Jebli and Youssef [41] presented that increase of international economic trade gave new opportunities to the agricultural sector in Tunisia to develop and to benefit from technology transfer of renewable energy, enabling it to become more competitive on the international markets and polluting less.

By evaluating the impacts of climate change, Baker et al. [42] highlighted that freer trade plays an important role in helping to buffer regional productivity shocks by applying a global model of agriculture and forestry on US agriculture and in the rest of the world.

Likewise, Dang and Konar [43] demonstrated that trade openness led to less water use in agriculture, reducing resource usage. Finally, Hallstrom et al. [44] showed that trade was crucial in realising the potential benefits of climate prediction.

\subsection{Agricultural Trade Might Have Positive or Negative Effect on the Environment}

Nine papers (Buckingham [45], Damodaran [46], Johansson et al. [47], Eickhout et al. [48], Schmitz et al. [49], Boerema et al. [50], Biewald et al. [51], Antonelli et al. [52], Belton and Little [53]) induced that there was a bidirectional, a positive or negative effect of agricultural trade on the environment, focusing mainly on environmental regulations and policy.

On the one hand, Buckingham [45] examined the historical development and treatment of environmental measures under the Agreement of World Trade Organization (between the United States, Mexico, Canada, and the EU). He concluded that it should reorient the acrimonious trade/environment debate to one which was less adversarial and more focused on achieving ecosystem health while continuing to improve international market access and trade relations.

On the other hand, Damodaran [46] stressed the integration of national and global environmental concerns with trade-related environmental regulations in the broader interests of sustainable agriculture in developing countries. In addition to that, he pointed out the biodiversity conservation needed to be institutionalised in terms of national laws and local community interventions. Moreover, the critical task is to secure the integration of national and global environmental concerns with trade-related environmental regulations.

Among others, Johansson et al. [47] analysed how the elimination of agricultural policy distortions would affect the liberalisation of global agricultural trade as well as the environmental quality in the United States. Their results suggested that environmental impacts stemming from trade shocks would fall within the average annual variation with different impacts by region and sector.

Moreover, Eickhout et al. [48] concluded that environmental and trade agreements must be sufficiently integrated or coordinated to working together to improve the environment and attain the benefits of free trade.

Regarding negative effects, in South Asia, Southeast Asia and the Middle East, Schmitz et al. [49] found evidence of increased water scarcity and water price decreases coinciding with increasing trade liberalisation. They recommended shrinking livestock consumption in developed countries as a potential solution for the environmental problem. In addition to the negative effects, the impact of increasing production of soybean in exporting countries (deforestation and grassland conversion) as well as in importing regions (decrease in permanent grassland by substitution of grass as feed) in Brazil and Argentina were analysed by Boerema et al. [50]. They proved that consumption choices in one region have real effects on the supply of ecosystem services at a large spatial scale.

Three articles concentrated on the relationship between trade and water use (Belton and Little [53], Biewald et al. [51], Antonelli et al. [52]). In the Middle East and South Asia, Biewald et al. [51] discovered that countries profit from trade by importing water-intensive crops from Southern Europe. On the other hand, export water-intensive agricultural goods from water-scarce sites were deteriorating local water-scarcity.

Researching the intra-EU agricultural trade and the virtual water flows, Antonelli et al. [52] concluded that international agricultural trade influenced water management, and the virtual water trade in the EU was dominated by only a few countries. In Thailand, Belton and Little [53] demonstrated 
that both sustainable integrated fish culture and unsustainable intensive small-scale inland shrimp culture were the outcomes of the globalization process.

\subsection{Effect of NAFTA on the Environment}

Only two articles were dedicated to measuring the environmental effects of NAFTA (North American Free Trade Agreement) between the US and Mexico. Abler and Pick [54] concluded that NAFTA was likely to be harmful to Mexican horticulture into a minor degree and beneficial for the U.S. In accordance, De Oca [55] highlighted that NAFTA enhanced energy trade along with the production of greenhouse gases (GHG). By contrast, greater corn trade produced deforestation and biodiversity loss in Mexico. In sum, NAFTA seemed to be damaging to the environment of Mexico and was more beneficial for the US (Table 2).

Table 2. Effects of NAFTA (North American Free Trade Agreement) on the environment.

\begin{tabular}{lll}
\hline The Environmental Effects of NAFTA & $\begin{array}{l}\text { Countries Where Environmental } \\
\text { Problems Are Caused by NAFTA }\end{array}$ & Main Beneficial Countries of NAFTA \\
\hline - & $\begin{array}{l}\text { NAFTA is likely to be harmful to } \\
\text { Mexican horticulture in a minor } \\
\text { degree, and beneficial for the U.S. }\end{array}$ & Mexico \\
\hline - $\quad \begin{array}{l}\text { NAFTA via energy trade enhancing } \\
\text { the production of greenhouse gasses } \\
\text { (GHG) at the global level } \\
\text { Canada }\end{array}$ & \\
\hline $\begin{array}{l}\text { NAFTA increased the potential of } \\
\text { consumption of fossil fuels }\end{array}$ & \\
\hline $\begin{array}{l}\text { NAFTA has been characterized by } \\
\text { a flow of energy resources from } \\
\text { Canada and Mexico to the US }\end{array}$ \\
$\begin{array}{l}\text { greater corn trade caused } \\
\text { deforestation and biodiversity loss } \\
\text { in Mexico }\end{array}$ \\
\hline $\begin{array}{l}\text { poor farmers expanded their } \\
\text { agricultural activity into marginal } \\
\text { forest and jungle areas to compensate } \\
\text { themselves for its income lost }\end{array}$ \\
\hline
\end{tabular}

Source: own composition.

\subsection{Negative Consequences of Free Trade on the Environment}

Trade acceleration and trade liberalization are considered as significant drivers of environmental impacts in the literature. Authors mentioned many factors of environmental pollution as negative consequences of free trade (Table 3) such as increasing GHG emissions, enhanced fertilizer use, threat to local and national food security, tropical deforestation and biodiversity loss, expanded agricultural activity in marginal forest and jungle areas, groundwater exhaustion, loss of species and drier climate (e.g., in Mexico and around Yellow river China).

Most negatively influenced countries were usually developing countries (China, Indonesia, India, Mexico, Brazil, Thailand, Malaysia, Vietnam) or least developed poor regions (the Maghreb, the Middle East, sub-Saharan Africa, Latin America, the Caribbean). A significant amount of $\mathrm{CO}_{2}$ emissions from land-use change were associated with exports from Brazil and Indonesia. Remarkable biodiversity loss mainly was observed in Africa and South America (especially in Brazil and Mexico).

By contrast, particularly developed countries such as the EU, the U.S. benefited the most from the positive environmental effect of trade (e.g., biofuel, soybean and palm oil trade). 
Table 3. The environmental concerns caused by trade.

\begin{tabular}{|c|c|c|}
\hline $\begin{array}{l}\text { The Major Consequences and } \\
\text { Climate Threats Caused by Trade }\end{array}$ & $\begin{array}{l}\text { Countries and Regions Where } \\
\text { Environmental Problems } \\
\text { Are Caused by Trade }\end{array}$ & $\begin{array}{l}\text { The Main Beneficiary of Positive } \\
\text { Environmental Impact of Trade }\end{array}$ \\
\hline - increasing GHG emissions & Countries & $\mathrm{EU}$ \\
\hline $\begin{array}{l}\text { enhanced fertilizer } \\
\text { endangering the local and } \\
\text { national food security }\end{array}$ & China, Indonesia, India & USA \\
\hline $\begin{array}{ll}\text { - } & \text { significant } \\
\text { environmental degradation }\end{array}$ & New Zealand, & developed countries \\
\hline $\begin{array}{l}\text { deforestation, tropical } \\
\text { deforestation and } \\
\text { biodiversity loss }\end{array}$ & Mexico, Brazil, & $\begin{array}{l}\text { the Middle East and } \\
\text { South Asian countries }\end{array}$ \\
\hline $\begin{array}{l}\text { - poor farmers expand their } \\
\text { agricultural activity into } \\
\text { marginal forest and } \\
\text { jungle areas }\end{array}$ & Thailand, Malaysia, Vietnam & \\
\hline $\begin{array}{l}\text { - groundwater exhaustion } \\
\text { - loss of species }\end{array}$ & Saint Lucia & \\
\hline $\begin{array}{l}\text { - } \text { drier climate } \\
\text { - deteriorating local } \\
\text { water scarcity }\end{array}$ & $\begin{array}{c}\text { Regions } \\
\text { Poor developing countries, } \\
\text { the Middle East, } \\
\text { sub-Saharan Africa, Maghreb, } \\
\text { Latin America, Amazonia, } \\
\text { Caribbean }\end{array}$ & \\
\hline
\end{tabular}

Source: own composition.

\subsection{Potential Solutions for Trade-Related Negative Impacts}

The literature analysed also declared which activities were responsible for the negative environmental effects of international (agricultural) trade (Table 4). On the one hand, most of the articles were linked with consumer's demand, domestic consumption or consumption choices as important factors setting the level of the trade-pollution nexus. In this context, shrinking livestock consumption in developed countries would be a potential solution for the environmental problem. On the other hand, trade-related environmental regulations also played a vital role in controlling the degree of environmental degradation. In consequence, trade and environmental agreements aspired to be mutually supportive but require substantial harmonisation between agreements at the international level.

Various solutions were suggested in the reduction of trade-related pollution in the selected literature. The most important solutions would be classified as consumer's demand, policy and regulation and R\&D related issues (Table 4). First, the United States and China urged co-operating to protect their agricultural resource bases [56]. Second, large investments in new technologies or the adoption of precision agriculture as well as the adoption of sustainable technologies, modern natural resource management [14] can mitigate the growth of the harmful effects of trade.

Furthermore, more R\&D investments in the agricultural sector (including, nutrients, pests, water and soils management, and improving plants' performance in semi-arid conditions and salty soils) is also needed [14] for reducing damaging effects. Finally, there is an urgent need for a more comprehensive, integrated approach to estimate the global impacts of food trade on the environment research and to improve the evaluation of key aspects of valuating resources depending on the local 
and regional biophysical and socio-economic context [57]. Last but not least, the applicability in decision-making, scenario analyses and accounting of deforestation and groundwater exhaustion will be still required in order to evaluate the pollution caused losses [57].

Table 4. The polluting activities and the solutions for mitigating environmental effects of trade.

\begin{tabular}{|c|c|}
\hline $\begin{array}{l}\text { Agricultural Activities/Sectors as Major } \\
\text { Contributors to Environmental Problems }\end{array}$ & $\begin{array}{l}\text { Solutions for Reducing the Negative Effects of International } \\
\text { Agricultural Trade on Environmental Pollution }\end{array}$ \\
\hline $\begin{array}{l}\text { Activities } \\
\text { - agricultural industrialization in } \\
\text { developing countries }\end{array}$ & $\begin{array}{l}\text { Demand side, changing consumption habits } \\
\text { - consumers, domestic consumption, consumer choices }\end{array}$ \\
\hline - livestock production & - shrink livestock consumption in developed countries \\
\hline - $\quad$ primary commodity export & Policy and regulation \\
\hline - overseas transport of agricultural products & - changing trade-related environmental regulations \\
\hline - water-intensive agricultural goods & - harmonization of environmental regulation \\
\hline - $\quad$ sectors & $\begin{array}{l}\text { Technology and innovation } \\
\text { - } \quad \text { adoption of precision agriculture }\end{array}$ \\
\hline - global corn production and trade & - large investments in new technologies \\
\hline - international banana trade & $\begin{array}{l}\text { - adoption of sustainable technologies, good natural } \\
\text { resource management }\end{array}$ \\
\hline - increasing bovine meat and palm oil exports & $\begin{array}{l}\text { R\&D } \\
\text { - investments in R\&D in the agricultural sector (including, } \\
\text { nutrients, pests, water and soils management, } \\
\text { and improving plants' performance in semi-arid } \\
\text { conditions and salty soils) }\end{array}$ \\
\hline $\begin{array}{l}\text { - unsustainable intensive small-scale inland } \\
\text { shrimp culture }\end{array}$ & $\begin{array}{l}\text { - applicability in decision-making, scenario analyses and } \\
\text { accounting of deforestation and groundwater exhaustion } \\
\text { will be required }\end{array}$ \\
\hline - intensive aquaculture and fisheries & $\begin{array}{l}\text { - a more comprehensive, integrated approach is needed to } \\
\text { estimate the global impacts of food trade on the } \\
\text { environment research is needed }\end{array}$ \\
\hline $\begin{array}{l}\text { - sugarcane, palm oil, rubber and } \\
\text { coffee production }\end{array}$ & \\
\hline - meat and dairy production & \\
\hline - biomass trade & \\
\hline
\end{tabular}

Source: own composition.

Finally, the environmental impacts of agricultural trade might appear at global (e.g., GHG emission) or regional level (e.g., land use). Frequently cited research gives insights as to the local impact of the global phenomena (expanded agricultural trade, free trade agreements), and as a result, our findings shed light on local problems and solutions.

\section{Conclusions}

The research addressed the environmental impacts of agricultural trade analysed through a systematic review of relevant literature published in recent years. In this analysis, we interpreted agricultural trade as an international, global phenomenon, however, environmental pollution was often investigated at a local, regional level by the articles. 
Based on the results of the literature review, most of the studies do not indicate a positive role of expanded agricultural trade or trade liberalisation in relation to the environment. Only a few scholars agreed that countries' environment could benefit from trade expansion or trade liberalisation. In addition, few researchers found that agricultural trade did not have a significant effect at all, or that it had a bidirectional effect (positive or negative) on environmental pollution or climate change.

The US, China, Mexico and Brazil were the most popular countries considered in the tradeenvironment nexus. The literature analysed suggested that crop (e.g., palm oil, rubber, coffee, soybean and biofuel), livestock and processed food sectors (meat, bovine meat, dairy products and fishery) were all responsible for environmental degradation in many countries.

Soil erosion, excessive water use in agriculture, water scarcity, deforestation and biodiversity loss are discussed as the major problems associated with accelerating trade in agri-food products. With trade liberalisation, increased water scarcity was reported in South Asia, Southeast Asia and the Middle East. In Brazil and Argentina, the negative impact of growing soybean production in exporting countries (deforestation and grassland conversion) as well as in importing regions (decrease in permanent grassland by substitution of grass as feed) were revealed.

The increasing GHG emissions and enhanced fertilizer use were also significant consequences of trade acceleration stimulating global warming and climate change.

Furthermore, tropical deforestation and biodiversity loss, expanded agricultural activity in marginal forest and jungle areas were explored in many developing countries as Brazil, India, Indonesia and Sub-Saharan Africa. In addition, groundwater exhaustion, loss of species, and drier climate all were the most important results of trade-related pollution in Africa and South America.

Articles investigating the role of NAFTA on the environment suggested that the agreement was rather harmful to Mexico and beneficial for the United States.

Several potential solutions were proposed by the literature in the reduction of trade-related environmental pollution. The literature points out that consumption choices in one region had real effects on the supply of ecosystem services at a large spatial scale. In particular, developed countries such as the EU, the U.S. benefited the most from the positive environmental effect of agricultural trade. Therefore, from the consumer's point of view, scholars underlined that shrinking livestock consumption especially in developed countries would significantly help to reduce environmental pollution.

From the production side, the large investments in new technologies or the adoption of precision agriculture as well as sustainable technologies and good natural resource management can mitigate the growth of the negative effects of agricultural trade. Furthermore, increasing agricultural R\&D investments (including nutrients, pests, water and soils management, and improving plants' performance in semi-arid conditions and salty soils) are also needed.

Results suggest that trade-related environmental regulations played a key role in controlling the degree of environmental degradation, motivating sustainable technologies. At the policy level, environmental and trade agreements must be sufficiently integrated at the national and international level to improve the quality of the environment and attain the benefits of free trade.

Last but not least, environmental improvement, growing renewable energy use, technology transfer and sustainable integrated fish culture were mentioned as the positive effect of globalized trade. Finally, some authors emphasized that intra-industry and inter-regional trade generally produced less pollution in the environment.

Author Contributions: Conceptualization, J.M.B. and A.J.; methodology, J.M.B. and A.J.; software, J.M.B. and A.J.; validation, J.M.B. and A.J.; formal analysis, J.M.B. and A.J.; resources, J.M.B. and A.J.; data curation, J.M.B. and A.J.; writing-original draft preparation, J.M.B. and A.J.; writing-review \& editing, J.M.B. and A.J.; visualization, J.M.B. and A.J.; supervision, J.M.B. and A.J.; project administration, J.M.B. and A.J.; funding acquisition, J.M.B. and A.J. All authors have read and agreed to the published version of the manuscript.

Funding: This research was supported by the National Research, Development and Innovation Office, Hungary, Project No. 128232 'Analysing the Environmental Effects of International Agro-food Trade' and 119669 'Competitiveness of Agriculture in International Trade: A Global Perspective'. The authors gratefully acknowledge the financial support.

Conflicts of Interest: The authors declare no conflict of interest. 


\section{References}

1. The State of Agricultural Commodity Markets. Agricultural Trade, Climate Change and Food Security; FAO: Rome, Italy, 2018; Available online: http://www.fao.org/3/19542EN/i9542en.pdf (accessed on 18 September 2019).

2. World Trade Statistical Review; World Trade Organization: Geneva, Switzerland, 2019; Available online: https://www.wto.org/english/res_e/statis_e/wts2019_e/wts2019_e.pdf (accessed on 6 January 2020).

3. Trade and the Environment. How are Trade and Environmental Sustainability Compatible? 2019. Available online: https://www.oecd.org/trade/topics/trade-and-the-environment/ (accessed on 18 September 2019).

4. Harris, J.M. Trade and the Environment. In A GDAE Teaching Module on Social and Environmental Issues in Economics; Global Development and Environment Institute, Tufts University: Medford, MA, USA, 2004.

5. Garsous, G. Trends in policy indicators on trade and environment. In OECD Trade and Environment Working Papers; OECD: Paris, France, 1 March 2019. [CrossRef]

6. Hanley, N.; Brennan, D. Economics of a low-carbon future. Earth Environ. Sci. Trans. R. Soc. Edinb. 2012, 103, 149-156. [CrossRef]

7. Brown, C.; Murray-Rust, D.; Van Vliet, J.; Alam, S.J.; Verburg, P.H.; Rounsevell, M.D. Experiments in globalisation, food security and land use decision making. PLoS ONE 2014, 9, e114213. [CrossRef] [PubMed]

8. De Lange, W.J.; Botha, A.M.; Oberholster, P.J. Towards tradable permits for filamentous green algae pollution. J. Environ. Manag. 2016, 179, 21-30. [CrossRef] [PubMed]

9. Delgado, J.A.; Shaffer, M.J.; Lal, H.; McKinney, S.P.; Gross, C.M.; Cover, H. Assessment of nitrogen losses to the environment with a Nitrogen Trading Tool (NTT). Comput. Electron. Agric. 2008, 63, 193-206. [CrossRef]

10. Appendini, K.; Liverman, D. Agricultural policy, climate change and food security in Mexico. Food Policy 1994, 19, 149-164. [CrossRef]

11. Saunders, C.; Wreford, A.; Cagatay, S. Trade liberalisation and greenhouse gas emissions: The case of dairying in the European Union and New Zealand. Aust. J. Agric. Resour. Econ. 2006, 50, 538-555. [CrossRef]

12. Lee, D.J.; Zhang, J. Efficiency, equity, and environmental implications of trade liberalization: A computable general equilibrium analysis. J. Int. Trade Econ. Dev. 2009, 18, 347-371. [CrossRef]

13. Schmitz, C.; Kreidenweis, U.; Lotze-Campen, H.; Popp, A.; Krause, M.; Dietrich, J.P.; Muller, C. Agricultural trade and tropical deforestation: Interactions and related policy options. Reg. Environ. Chang. 2015, 15, 1757-1772. [CrossRef]

14. Flachsbarth, I.; Willaarts, B.; Xie, H.; Pitois, G.; Mueller, N.D.; Ringler, C.; Garrido, A. The role of Latin America's land and water resources for global food security: Environmental trade-offs of future food production pathways. PLOS ONE 2015, 10, e0116733. [CrossRef]

15. Moon, W. Is agriculture compatible with free trade? Ecol. Econ. 2011, 71, 13-24. [CrossRef]

16. Rauf, A.; Zhang, J.; Li, J.; Amin, W. Structural changes, energy consumption and Carbon emissions in China: Empirical evidence from ARDL bound testing model. Struct. Chang. Econ. Dyn. 2018, 47, 194-206. [CrossRef]

17. Zhao, X.; Yang, H.; Yang, Z.; Chen, B.; Qin, Y. Applying the Input-Output Method to Account for Water Footprint and Virtual Water Trade in the Haihe River Basin in China. Environ. Sci. Technol. 2010, 44, 9150-9156. [CrossRef]

18. Zhang, Z.Y.; Yang, H.; Shi, M.J.; Zehnder, A.J.B.; Abbaspour, K.C. Analyses of impacts of China's international trade on its water resources and uses. Hydrol. Earth Syst. Sci. 2011, 15, 2871-2880. [CrossRef]

19. Saikku, L.; Soimakallio, S.; Pingoud, K. Attributing land-use change carbon emissions to exported biomass. Environ. Impact Assess. Rev. 2012, 37, 47-54. [CrossRef]

20. DeFries, R.; Herold, M.; Verchot, L.; Macedo, M.N.; Shimabukuro, Y. Export-oriented deforestation in Mato Grosso: Harbinger or exception for other tropical forests? Philos. Trans. R. Soc. B Biol. Sci. 2013, 368, 20120173. [CrossRef] [PubMed]

21. Henders, S.; Persson, U.M.; Kastner, T. Trading forests: Land-use change and carbon emissions embodied in production and exports of forest-risk commodities. Environ. Res. Lett. 2015, 10, 125012. [CrossRef]

22. Iriarte, A.; Almeida, M.G.; Villalobos, P. Carbon footprint of premium quality export bananas: Case study in Ecuador, the world's largest exporter. Sci. Total Environ. 2014, 472, 1082-1088. [CrossRef] [PubMed]

23. Walters, B.B. Explaining rural land use change and reforestation: A causal-historical approach. Land Use Policy 2017, 67, 608-624. [CrossRef]

24. Chang, J.; Symes, W.S.; Lim, F.; Carrasco, L.R. International trade causes large net economic losses in tropical countries via the destruction of ecosystem services. Ambio 2016, 45, 387-397. [CrossRef] 
25. Chaudhary, A.; Kastner, T. Land use biodiversity impacts embodied in international food trade. Glob. Environ. Chang. 2016, 38, 195-204. [CrossRef]

26. Drabo, A. 2017 Climate change mitigation and agricultural development models: Primary commodity exports or local consumption production? Ecol. Econ. 2017, 137, 110-125. [CrossRef]

27. Yau, Y.Y.; Thibodaeu, B.; Not, C. Impact of cutting meat intake on hidden greenhouse gas emissions in an import-reliant city. Environ. Res. Lett. 2018, 13, 064005. [CrossRef]

28. Chakravorty, U.; Fisher, D.K.; Umetsu, C. Environmental effects of intensification of agriculture: Livestock production and regulation. Environ. Econ. Policy Stud. 2007, 8, 315-336. [CrossRef]

29. Weinzettel, J.; Wood, R. Environmental Footprints of Agriculture Embodied in International Trade: Sensitivity of Harvested Area Footprint of Chinese Exports. Ecol. Econ. 2018, 145, 323-330. [CrossRef]

30. Nesme, T.; Metson, G.S.; Bennett, E.M. Global phosphorus flows through agricultural trade. Glob. Environ. Chang. 2018, 50, 133-141. [CrossRef]

31. Ervin, D.E. Trade agreements, agriculture, and the environment in developing countries: Discussion. Am. J. Agric. Econ. 1993, 75, 799-800. [CrossRef]

32. Beghin, J.; Dessus, S.; Roland-Holst, D.; Van der Mensbrugghe, D. The trade and environment nexus in Mexican agriculture. A general equilibrium analysis. Agric. Econ. 1997, 17, 115-131. [CrossRef]

33. Chen, Z.; Ni, W.; Xia, L.; Zhong, Z. Structural decomposition analysis of embodied carbon in trade in the middle reaches of the Yangtze River Environmental. Sci. Pollut. Res. 2019, 26, 816-832. [CrossRef]

34. Bourgeon, J.M.; Ollivier, H. Is bioenergy trade good for the environment? Eur. Econ. Rev. 2012, 56, 411-421. [CrossRef]

35. Carter, C.A. Trade, agriculture, and the environment in developing countries: Discussion. Am. J. Agric. Econ. 1993, 75, 801-802. [CrossRef]

36. Hassan, R.M. Trade liberalisation and the environment: The case of agriculture in South Africa. Agrekon 1997, 36, 407-433. [CrossRef]

37. Leitao, N.C. Environmental change and agriculture: The role of international trade. Afr. J. Agric. Res. 2011, 6, 4065-4068. Available online: http://www.academicjournals.org/AJAR (accessed on 15 September 2019). [CrossRef]

38. Billen, G.; Lassaletta, L.; Garnier, J. A vast range of opportunities for feeding the world in 2050: Trade-off between diet, $\mathrm{N}$ contamination and international trade. Environ. Res. Lett. 2015, 10, 025001. [CrossRef]

39. Cors, T.A. Biosafety and international trade: Conflict or convergence? Int. J. Biotechnol. 2000, 2, $27-43$. [CrossRef]

40. Martinez-Melendez, L.A.; Bennett, E.M. Trade in the US and Mexico helps reduce environmental costs of agriculture. Environ. Res. Lett. 2016, 11, 055004. [CrossRef]

41. Jebli, B.M.; Youssef, B.S. Renewable energy consumption and agriculture: Evidence for cointegration and Granger causality for Tunisian economy. Int. J. Sustain. Dev. World Ecol. 2017, 24, 149-158. [CrossRef]

42. Baker, J.S.; Havlík, P.; Beach, R.; Leclère, D.; Schmid, E.; Valin, H.; Cole, J.; Creason, J.; Ohrel, S.; McFarland, J. Evaluating the effects of climate change on US agricultural systems: Sensitivity to regional impact and trade expansion scenarios. Environ. Res. Lett. 2018, 13, 064019. [CrossRef]

43. Dang, Q.; Konar, M. Trade Openness and Domestic Water Use. Water Resour. Res. 2018, 54, 4-18. [CrossRef]

44. Hallstrom, D.G. Interannual climate variation, climate prediction, and agricultural trade: The costs of surprise versus variability. Rev. Int. Econ. 2004, 12, 441-455. [CrossRef]

45. Buckingham, D.E. Does the World Trade Organization care about ecosystem health? The case of trade in agricultural products. Ecosyst. Health 1998, 4, 92-108. [CrossRef]

46. Damodaran, A. Conflict of trade-facilitating environmental regulations with biodiversity concerns: The case of coffee-farming units in India. World Dev. 2002, 30, 1123-1135. [CrossRef]

47. Johansson, R.C.; Cooper, J.; Peters, M. An agri-environmental assessment of trade liberalization. Ecol. Econ. 2006, 58, 37-48. [CrossRef]

48. Eickhout, B.; van Meijl, H.; Tabeau, A.; van Rheenen, T. Economic and ecological consequences of four European land use scenarios. Land Use Policy 2007, 24, 562-575. [CrossRef]

49. Schmitz, C.; Lotze-Campen, H.; Gerten, D.; Dietrich, J.P.; Bodirsky, B.; Biewald, A.; Popp, A. Blue water scarcity and the economic impacts of future agricultural trade and demand. Water Resour. Res. 2013, 49, 3601-3607. [CrossRef] 
50. Boerema, A.; Peeters, A.; Swolfs, S.; Vandevenne, F.; Jacobs, S.; Staes, J.; Meire, P. Soybean trade: Balancing environmental and socio-economic impacts of an intercontinental market. PLoS ONE 2016, 11, e0155222. [CrossRef]

51. Biewald, A.; Rolinski, S.; Lotze-Campen, H.; Schmitz, C.; Dietrich, J.P. Valuing the impact of trade on local blue water. Ecol. Econ. 2014, 101, 43-53. [CrossRef]

52. Antonelli, M.; Tamea, S.; Yang, H. Intra-EU agricultural trade, virtual water flows and policy implications. Sci. Total Environ. 2017, 587-588, 439-448. [CrossRef]

53. Belton, B.; Little, D. The development of aquaculture in central Thailand: Domestic demand versus export-led production. J. Agrar. Chang. 2008, 8, 123-143. [CrossRef]

54. Abler, D.G.; Pick, D. NAFTA, agriculture, and the environment in Mexico. Am. J. Agric. Econ. 1993, 75, 794-798. [CrossRef]

55. De Oca, G.S.M. Quantifying NAFTA Environmental Impacts: Energy and Agriculture. CSERGE Working Paper EDM 08-02. 2008. Available online: https://www.econstor.eu/handle/10419/48820 (accessed on 18 September 2019).

56. Brown, L.R.; Halweil, B. China's water shortage could shake world food security. World Watch 1998, 11, 10-21. Available online: https://www.academia.edu/1037548/Chinas_water_shortage_could_shake_world_ food_security (accessed on 18 September 2019).

57. Dalin, C.; Rodríguez-Iturbe, I. Environmental impacts of food trade via resource use and greenhouse gas emissions. Environ. Res. Lett. 2016, 11, 035012. [CrossRef]

(C) 2020 by the authors. Licensee MDPI, Basel, Switzerland. This article is an open access article distributed under the terms and conditions of the Creative Commons Attribution (CC BY) license (http://creativecommons.org/licenses/by/4.0/). 